\title{
Open vascular surgery procedures: how will we learn to do them and will they have the same quality?
}

\author{
Procedimentos de cirurgia vascular aberta: como aprender a \\ realizá-los e será que terão a mesma qualidade?
}

Peter Lawrence*

\begin{abstract}
The progression toward endovascular procedures for primary treatment of vascular disease, from repair of abdominal aortic aneurysms (AAA) to endotherapy for all aneurysmal and occlusive vascular disease, has gradually occurred over the past 15 years. Only financial limitations placed by government agencies and insurance companies have slowed the progression toward primary endovascular therapy for all vascular diseases. In the USA, carotid stenting and renal angioplasty are two areas where limitations have recently been proposed or placed on the use of endovascular therapy. Patients are demanding endovascular approaches, and since physicians are better reimbursed for endovascular therapy than open surgery, many physicians, as well as patients, are embracing primary endovascular approaches, in spite of limited long-term data comparing endovascular and open approaches in many vascular beds. With the increased use of endovascular approaches, open vascular procedures are performed less frequently and are often reserved for patients with the most complex vascular problems. For example, endovascular repair of AAA is commonly performed in patients with infrarenal aneurysms with a long neck, while open surgical repair is usually reserved for pararenal and juxtarenal aneurysms which require suprarenal aortic clamping. Some vascular surgeons have reduced operative risks by limiting their practices to specific procedures and referring complex cases to other vascular surgeons, but there
\end{abstract}

is still a reduced volume of open procedures in many surgical practices that previously had a large open surgical experience.

Historically, operative mortality has been reduced to very low levels by performing a high volume of cases and focusing practices exclusively on vascular surgery. With the reduced number of cases and the increased complexity of the remaining open cases, who will be performing these open procedures in the future, and how will the next generation of open vascular surgeons be trained? Many vascular surgeons who are involved in training programs are concerned about this problem. The remaining open cases in most academic training centers are often complex and therefore not optimal for training; if training is performed on these cases, there may be a significant risk to the patient. What are the options for future vascular care that will keep the outcomes of open cases as good as they are today and competitive with endovascular procedures, in terms of outcomes, as their frequency decreases?

There are several possible scenarios: 1) the results of open procedures, which will be performed less frequently, will worsen, leading to a more rapid move toward an all endovascular approach to most vascular diseases; 2) higher risk open vascular surgery procedures will be regionalized to a small group of surgeons who perform these procedures in high volume; 3 ) there

* MD. Professor of Surgery and Chief of Vascular Surgery, University of California (UCLA), Los Angeles, USA. Director, Gonda (Goldschmied) Vascular Center, Gonda (Goldschmied) Wound Treatment and Clinical Tissue Engineering Center, UCLA, Los Angeles, USA.

No conflicts of interest declared concerning the publication of this editorial. 
will be the development of better ways of training surgeons for simple and complex open procedures that will not put patients at risk. These new training techniques include an increased use of DVD's and videotapes, procedure specific simulators, large animal training, and regional centers where high risk open cases are performed and where training will be incorporated in the care of all open vascular cases.

Vascular surgeons have the responsibility to maintain and improve their competence in both open and endovascular procedures. All of us need to develop our own personal strategies to maintain our own competence. It may be that the vascular surgeon of the future will not be competent in both endovascular and open procedures and that we will need to both regionalize vascular care and sub-specialize within vascular surgery to maintain the high quality outcomes that we have become used to.

\section{Referências}

1. Pandy VA, Black SA, Lazaris AM, Allenberg JR, Eckstein $\mathrm{HH}$, Hagmuller GW, et al. Do workshops improve the technical skill of vascular surgical trainees? Eur J Vasc Endovasc Surg. 2005;43:539-545.

2. Wanzel KR. Teaching the surgical craft: From selection to certification. Curr Probl Surg. 2002;39:573-659.

3. Jimenez JC, Lawrence PF, Rigberg DA, Quinones-Baldrich WJ. Technical modifications in endoscopic vein harvest facilitate its use in lower extremity limb salvage procedures. J Vasc Surg. 2007;45:549-53.

4. Dawson DL, Meyer J, Lee ES, Pevec WC. Training with simulation improves residents' endovascular procedure skills. J Vasc Surg, 2007;45:149-154.

\section{Colega Associado da SBACV}

Você está convidado a participar do crescimento e consolidação do J Vasc Bras - como autor, leitor ou revisor.

Leia e divulgue; conheça as normas e submeta seus trabalhos.

Jornal Vascular Brasileiro - Secretarial Editorial Rua Maraguape, 72, loja 01 CEP 90690-380 - Porto Alegre - RS - Fone (51) 3012-0575 